\title{
Securitization, Trade Credit and The Nature of Goods
}

\author{
Chris Harris \\ Elon University \\ Donna Dudney \\ University of Nebraska-Lincoln
}

We examine whether non-financial firms use securitization as a tool to increase trade credit. Our results suggest that securitization use is associated with increased investment in trade receivables. The impact of securitization on sales growth and market share depends on the nature of the goods sold, with significant positive increases only for firms selling services or differentiated goods. Securitization is not associated with increases in short-term income.

\section{INTRODUCTION}

Trade receivables facilitate the sale of goods or services to customers while simultaneously delaying receipt of payment. The work of many different researchers has highlighted the nontrivial economic importance of trade credit, with mean levels between $18 \%-21 \%$ of total assets for public firms in the United States (Mian and Smith (1992); Molina and Preve (2009); Hill, Kelly and Lockhart (2012)).

Prior literature has examined the ability of selling firms to generate sales growth by offering trade credit (Meltzer (1960); Nadiri (1969); Schwartz (1974); Petersen and Rajan (1997); Molina and Preve (2009)). Hill, Kelly and Lockhart (2012) examine shareholder wealth implications of supplying financing to customers and find that excess stock returns are associated with increases in trade receivables. However, a firm's ability to offer trade credit is limited if the firm has low liquidity. Firms may have to reduce their offering of trade credit when liquidity concerns will no longer allow them to delay the receipt of cash, even if doing so may reduce sales (Molina and Preve 2009). Securitization is a process that allows a firm to sell its accounts receivables and receive the promised cash payments prior to the receivables due dates, thus providing liquidity to financially constrained firms.

This paper looks at the use of securitization by non-financial firms as a tool to increase investment in trade credit, and investigates whether the use of trade credit securitization leads to increased sales growth, improved earnings, and market share gains. We find that securitization use is associated with increases in investments in trade credit. However, the impact of securitization on sales growth and market share gains varies based on the nature of the goods sold, as defined by Giannetti, Burkart, and Ellingsen (2011). We find that securitization use is associated with sales and market share increases for firms in service and differentiated goods industries, but not for firms selling standardized goods. Increases in sales growth and market share do not appear to translate into increases in short-term income.

This paper contributes a previously unestablished link between the trade credit and securitization literature. By understanding which firms benefit most from the use of securitization, this paper helps to 
explain why so few firms utilize a securitization facility. Part of the answer, established by this paper, may be that not all types of firms realize trade credit benefits from securitization.

\section{THEORIES, FINANCING ALTERNATIVES AND ACCOUNTING CONVENTIONS}

\section{Why Firms Extend Trade Credit}

Prior research has examined why trade credit exists and why credit terms available directly from selling firms may be preferable to credit offered by financial intermediaries. Researchers have developed at least four theories: 1) transactions costs theory, 2) warranty of product quality, 3) value of trade credit as a commitment device, and 4) financing theory.

Transactions cost theory is described by Ferris (1981). Ferris demonstrates that the transactions cost of paying for goods may be reduced through the use of trade credit. The logic is that trade credit allows for a customer firm to build its inventory and make payments periodically, as opposed to paying immediately when goods are received. The use of trade credit thus allows the buyer a way to smooth production cycles and build inventory in preparation for seasonal spikes in sales.

The warranty of product quality theory notes that the granting of trade credit by sellers reduces buyer concerns about product quality and serves as a warranty against product defects (Long, Malitz and Ravid (1993); Lee and Stowe (1993)). If the product fails prior to the trade credit payment date, the buyer can use the leverage of non-payment to force the supplier to address product quality concerns.

Trade credit may also have value as a commitment device. Dass, Kale and Nanda (2015) argue that sellers must make relationship-specific investments in order to ensure that the product delivered to the buyer is exactly what the buyer wants, particularly in the case of specialized products and services. Trade credit offers buyers a mechanism to ensure relationship-specific investments by the seller, as the delay and risk of non-payment (by the buyer) if relationship-specific investments have not been made provides an incentive for the seller to invest appropriately.

Financing theory argues that trade credit can improve sales for sellers by resolving financial and liquidity constraints of buyers. As noted by Petersen and Rajan (1997), if selling firms have excess liquidity or a comparative advantage in obtaining outside financing, they can pass this advantage on to small, credit constrained buyers. Suppliers may be able to reduce information asymmetry compared to banks, as suppliers often have frequent interactions with buyers. Because the supplier may be able to generate a higher liquidation value for repossessed goods (particularly if the goods are specialized in nature), suppliers may have an advantage over banks in providing short-term financing through trade credit (Peterson and Rajan, 1997); Longhofer and Santos, 2003). Petersen and Rajan (1997) provide evidence that firms suffering financially use the extension of trade credit to attempt to maintain their sales. They also find that fast-growing firms seem to extend more trade credit, perhaps in an attempt to buy sales. Molina and Preve (2009) support the theory that firms facing profitability problems will increase their level of trade credit in a bid to buy sales. They additionally find that decreasing levels of trade credit can impose a cost on firms in the form of lower sales growth, lower income growth and lower stock returns. If a firm enters financial distress, decreasing trade credit can increase the costs of financial distress.

Giannetti, Burkart and Ellingsen (2011) show that trade credit financing is related to the nature of the transacted good. They find that suppliers of differentiated products utilize accounts receivable trade credit more than suppliers of standardized products. Their findings are consistent with the idea that borrower opportunism is less of a problem with differentiated goods (and services) because differentiated products have low diversion value, or because buyers know that it will be hard to replace specialized suppliers that produce a unique or customized product. This makes it less likely that customers will switch suppliers, and more likely that the buyer will try to maintain a strong relationship with the seller, making it less risky for the seller to offer trade credit to buyers of services and differentiated goods (Cunat 2007). Research by Hill, Kelly, and Lockhart (2012) complements Giannetti, Burkart and Ellingsen (2011). Hill et al find that increases in trade credit are associated with excess stock returns, and the association is stronger for firms with less ability to dictate terms to buyers. 
Our work relates most closely to the financing theory of trade credit. A firm can only use the extension of trade credit to maintain or buy sales if the firm has excess liquidity. Our research examines whether firms use the securitization of receivables as a mechanism to generate liquidity and allow the extension of additional trade credit. We also examine whether the use and effectiveness of trade credit is related to the nature of the product sold.

\section{Factoring versus Securitization}

While the above theories for offering trade credit may explain the use of trade credit, they do not specifically address how firms choose to manage the economically significant levels of accounts receivable that result from offering trade credit.

Mian and Smith (1992) summarize several of the available alternatives. One alternative is for the firm to maintain the receivables as general corporate credit. In this case, the firm can more rigorously internalize borrower credit quality decisions and decisions on the amount of credit to offer (i.e. the firm maintains direct control over the extension of credit and credit collection). However, the firm also has the ability to sell the receivables by using a factor or by utilizing a securitization facility. By entering into an agreement with a factor or by utilizing a securitization facility, firms are making a choice to extend trade credit while simultaneously making the choice not to wait to collect the cash (from the buyers) for those receivables.

Factoring is a method by which a firm sells a portion of its receivables to a third party. The third party is referred to as the 'factor firm'. The factor firm assesses the receivables to be sold and decides on an amount it is willing to pay to assume ownership. Prior literature has discussed the determinants of factoring (Mian and Smith (1992); Smith and Schnucker (1994)). These papers find factoring is typically used by smaller firms that may not have the resources necessary to internalize the credit management process.

Securitization is the process by which a firm establishes a subsidiary, frequently called a special purpose entity or SPE. This SPE issues debt and the cash received from this debt issue is used to purchase receivables from the parent company. The receivables purchased by the SPE are then collected to make payments to the bondholders of the SPE. A unique feature of the securitization process is that, in many cases, the SPE is considered 'bankruptcy remote'. This bankruptcy remoteness means that if the parent company were to go bankrupt, the creditors of the parent company do not have recourse to the assets of the SPE. Likewise, should the receivables held by the SPE default, the creditors of the SPE do not have recourse to the parent company.

Lemmon et al (2014) study the use of securitization among nonfinancial firms and find that the median size of securitizing firms is 8-12 times larger than their industry medians, and the median level of accounts receivable, debt, earnings and growth rates are all higher than industry medians. These results demonstrate a divide between firms that elect to use a factor and those that choose to securitize their receivables. This study focuses on firms electing securitization as a method for managing trade receivables.

Although firms choosing to securitize are larger with higher growth rates than the median in their industries, they may also be firms struggling to maintain growth and liquidity. The idea that securitization firms, although large and profitable, may also be firms that are potentially experiencing a slow-down in growth and profitability is further supported by Lemmon et al (2014). They conduct a probit analysis to relate the probability that a firm will securitize to certain firm characteristics measured at the beginning of that firm year, and find positive significance for size, accounts receivable, debt, BBB and $\mathrm{BB}$ bond ratings, and if the firm had a recent debt downgrade. They find negative significance for earnings, R\&D and short-term bond rating. Thus, all else equal, the decision to securitize is related to the firm having more debt, recently experiencing a debt downgrade, and having lower earnings and less R\&D. Lemmon et al (2014) find that firms initiating a securitization facility experience positive abnormal stock and bond returns. They also show that the initiation of securitization is associated with decreases in existing debt, indicating that firms may use the securitization proceeds to repay existing debt. 


\section{Accounting Treatment of Securitized Receivables}

The accounting treatment of SPEs is governed by a series of Financial Accounting Standards Board (FASB) rulings. SPE financials must be consolidated unless that SPE meets specified FASB requirements. When the SPE is consolidated on the balance sheet, the accounts receivable and debt issued by the SPE will remain on the parent company balance sheet. When the SPE is unconsolidated, the accounts receivable and debt issued by the SPE do not appear on the parent firm's balance sheet. The rules regarding whether or not the SPE is consolidated or unconsolidated have changed through time. As the accounting treatment for the securitized receivables has changed, it has put more pressure on securitizing firms to include the SPE in their consolidated financial statements. While the change in accounting standards requires more SPEs to be consolidated, the ability for the sale of receivables to qualify as a 'true sale' still allows for unconsolidated securitization facilities. If the SPE is not consolidated, then the transfer of receivables to the SPE is treated like a collateralized borrowing. A more detailed description of the FASB changes in accounting treatment for securitization is provided in Appendix A.

When the receivables are sold to the SPE, the parent company may receive cash for less than $100 \%$ of the face value of receivables. The difference between receivables transferred to the SPE and cash received by the parent company is generally referred to as the 'retained interest' or 'residual interest'. If the SPE is not consolidated, the residual interest is still recorded on the parent company's balance sheet as an asset. Therefore, the treatment of the receivables sold focuses on the amount of receivables for which the parent company received payment. Understanding the accounting effects of securitization is important because examination of securitization and trade credit relies on accounting data.

In order to better understand the effect of securitization on the financial statements, Dechow and Shakespeare (2009) provide an example of the accounting differences between consolidated and unconsolidated SPE's. This example is provided in Appendix B for those readers who are unfamiliar with these differences.

As shown in Appendix B, when the SPE is not consolidated there will be a decrease in both accounts receivable and total assets. These decreased numbers will be the numbers reported in Compustat. Therefore, in order to accurately compare firms with consolidated and unconsolidated SPE's, the Compustat data must be adjusted to reflect the unconsolidated receivables held at the SPE.

\section{Hypotheses and Empirical Model Specifications}

Based on previous findings regarding the characteristics of firms that choose to securitize (Mills and Newberry, 2004; Lemmon et al, 2014), it would appear securitizing firms may have had strong growth in the past, but are now experiencing declining profitability and declining liquidity. Securitization may allow these firms to maintain or increase sales by offering additional trade credit. Securitization provides a mechanism to avoid the liquidity problems associated with waiting for cash receipts from accounts receivables, thus allowing firms to both increase their investment in trade credit as well as increase sales. This brings us again to the conflict of firms desiring to extend additional trade credit, but suffering from cash flow problems (Petersen and Rajan (1997); Molina and Preve (2009)). This paper extends prior research by testing whether securitization is used by firms to increase trade credit, and whether securitization is associated with increases in sales growth. After identifying the relationship between securitization, trade credit, and sales growth, we additionally examine whether securitization is associated with additional short-term income or market share growth for the firm, and whether the strength of this association depends on the nature of the good financed.

If securitization allows firms to increase trade credit to maintain sales, there should be a direct relation between a firm's use of securitization and the firm's investment in trade credit. Thus, our first hypothesis is:

H1: The relation between securitization and investment in trade receivables is positive. 
Giannetti, Burkart, and Ellingsen (2011) show that the use of trade credit varies with the nature of the good, with trade credit used more frequently by suppliers of services and differentiated goods. Given this result, we would expect the relation between securitization and the investment in trade credit to be stronger for firms providing services and differentiated goods (called Trade Credit firms, or TC Firms) than for firms producing standardized goods (called Non-Trade Credit firms, or Non-TC Firms).

Hla: The relation between securitization and investment in trade receivables is stronger for Trade Credit firms than for Non-Trade Credit firms.

Additionally, if offering trade credit allows a firm to attract customers who otherwise would not purchase the firm's products, securitization will lead to an increase in sales. Similarly, if trade credit is used more frequently by TC firms, the impact of securitization on sales growth should be greater for these firms.

H2: $\quad$ The relation between securitization and sales growth is positive.

H2a: The relation between securitization and sales growth is stronger for Trade Credit firms than for Non-Trade Credit firms.

Peterson and Rajan (1997) suggest that firms may increase trade credit in an attempt to increase market share. If securitization allows for firms to increase their investment in trade credit which translates into positive sales growth, we expect to see a positive relationship between market share growth and securitization.

H3: The relation between securitization and market share growth is positive.

H3a: The relation between securitization and market share growth is stronger for Trade Credit firms than for Non-Trade Credit firms.

If securitization can increase sales and market share, and if profit margins remain the same, the firm should also experience a growth in short-term profits.

H4: The relation between securitization and income growth is positive.

H4a: The relation between securitization and income growth is stronger for Trade Credit firms than for Non-Trade Credit firms.

Our methodology initially follows that of Molina and Preve (2009) who use trade receivables divided by sales, multiplied by 360 as the dependent variable. This is the ratio of trade receivables to sales, measured in days. We similarly follow this measure for investment in trade receivables. We additionally include an independent securitization variable (Amtrecta) to determine the impact of securitization on the firm's offering of trade credit. Amtrecta is calculated as the total amount of money received by the firm from the sale of securitized receivables to the SPE, as a percentage of total assets. Calculating the total assets of the firms varies based on the consolidation status of the securitization SPE. Firms that securitize their receivables will not have the receivables of the SPE included in either the trade receivables (RECTR) or total assets (AT) of the firm when the SPE is not consolidated with the firm's financial statements. Our goal is to compare all companies as if the securitization facilities were consolidated. Therefore, when the SPE is unconsolidated, the outstanding balance of trade receivables held at the SPE is added to the total assets number used in the denominator of Amtrecta. An alternative to the Amtrecta variable would be to use a dummy variable to indicate whether a firm securitizes receivables in a particular year. While an indicator variable captures the presence of securitization activity in a particular year, an advantage of Amtrecta is that it also captures the level of securitization activity. In our robustness tests, we use an indicator variable for securitization, and obtain similar results. We also include firm characteristics that were shown by Lemmon et al (2014) to be related to securitization.

Our initial model specification is: 
Days Receivables $_{i, t}=\alpha_{l}+\beta_{1}$ Financial Distress $_{i, t-1}+\beta_{2}$ Payables $_{i, t-1}+\beta_{3}$ Leverage $_{i, t-1}+$ $\beta_{4}$ Sales Growth $_{i, t-1}+\beta_{5}$ Turnover $_{i, t-1}+\beta_{6}$ Amtrecta $_{i, t-1}+\beta_{7}$ LnAssets $_{i, t-1}+$ $\beta_{8}$ Market-to-Book $_{i, t-1}+\beta_{9}$ Earnings/Assets $_{i, t-1}+\beta_{10}$ R\&D $_{i, t-1}+\beta_{11}$ PPE $_{i, t-1}+\beta_{12}$ LnAge $_{i, t-1}+$ $\beta_{13}$ LTDebtDummy $_{i, t-1}+\beta_{14}$ STDebtDummy $_{i, t-1}+\beta_{15} B B B_{i, t-1}+\beta_{16} B B_{i, t-1}+\beta_{17} B_{i, t-1}+\beta_{18}$ Below $B_{i, t-1}+\varepsilon_{i, t}$

All variables are described in Appendix C. The model results are calculated for the full sample, and for split samples of TC firms and Non-TC firms. As an alternative to split sample analysis, we could have created indicator variables for TC firms and Non-TC firms, and interacted these variables with the securitization variable. However, this approach inherently assumes that the coefficients on the remaining variables are the same for both Trade Credit and Non Trade Credit firms. Use of a split sample methodology does not enforce this constraint.

After establishing a positive relation between securitization and trade receivables, we assess the impact securitization has on sales, income and market share growth, and analyze whether the impact of securitization is more pronounced for TC firms. Giannetti, Burkart and Ellingsen (2011) find that suppliers of services and differentiated products utilize accounts receivable trade credit more than suppliers of standardized products. If trade credit is more important for TC firms, we expect to see greater sales, income and market share growth benefits for these firms. To examine this, we follow in the spirit of Molina and Preve (2009) by looking at industry-adjusted growth in sales and income and changes in market share. We start with Molina and Preve's model and include a variable for securitization (Amtrecta). In all cases, the model results are calculated for the full sample, and for the TC firms and Non-TC firms split samples. The firm fixed effects regression model specification is shown below, with all variables defined in Appendix C.






\section{DATA SOURCES, SAMPLE CONSTRUCTION, AND DESCRIPTIVE STATISTICS}

\section{Data Sources and Sample Construction}

Securitization data is not provided by Compustat, so to examine securitization's impact on trade credit decisions, we gather securitization data directly from company $10-\mathrm{K}$ filings. Our initial sample includes all firms in the Compustat database from fiscal years 1996 through 2010, excluding financial firms (SIC codes 6000 - 6999) and regulated utilities (SIC codes $4900-4999$ ). To collect securitization data on these firms, we first identify those firms using a securitization facility by following the search methodology of Lemmon et al (2014) by searching the terms 'securitization', 'securitisation', 'securitized', 'securitised'. We additionally search the term 'receivable(s)' in conjunction with the use of either 'sale(s)', 'sell(s)', or 'sold'. This search resulted in 20,811 firm 10-Ks with potential results. By reading through the $10-\mathrm{Ks}$, we verify the existence of an SPE. For those firms with an SPE, we identify, where available, the limit on the level of receivables that can be sold to the SPE facility, the actual amount of receivables sold to the SPE, the amount of payment received for the receivables sold, the retained interest in the SPE (the difference between amount sold and amount received), and the date the securitization program began. After combining this securitization data with the Compustat data, and eliminating firm-years missing the required financial data or having nonpositive values for the market value of equity and net assets, our final sample consists of an unbalanced panel of 51,737 firm year observations from 1996 to $2010,1,672$ of which use securitization.

\section{Descriptive Statistics}

Table 1 provides summary statistics for all variables used in the subsequent analysis, while Table 2 provides descriptive statistics for the split samples used in our analysis. Panel A includes firm year observations for firms using a securitization facility. Panel B provides summary statistics for nonsecuritizing firm-year observations. Statistics for firm year observations for TC firms (firms providing services or differentiated goods) and Non-TC firms (firms providing standardized goods) are provided in Panels C and D, respectively. Data for all variables are windsorized at the $1 \%$ and $99 \%$ levels. 


\section{TABLE 1 \\ DESCRIPTIVE STATISTICS FULL SAMPLE}

This table provides summary statistics for variables included in our analysis. The sample includes all nonfinancial and nonutility firms in Compustat for fiscal years 1996 through 2010. Trade Receivables is trade receivables divided by total assets. If a firm has an unconsolidated SPE, Trade Receivables is the sum of trade receivables plus the outstanding balance of a trade receivables held at the SPE, divided by total assets plus the trade receivables held at the SPE. Days Receivables is the firm's investment in trade receivables measured by the ratio of trade receivables to daily sales. Financial Distress is an indicator variable equal to one if the firm is in financial distress according to the Asquith, Gertner and Scharfstein (1990) definition. Payables is accounts payables as a percentage of total assets. Leverage is the book value of debt divided by total assets. Sales Growth is the growth in firm sales. Turnover is Inventory Turnover, computed as cost of goods sold divided by inventory. Amtrecta is the total amount of money received for securitized receivables as a percentage of total assets. LnAssets is the natural log of total assets. Marketto-Book is the ratio of the market value to book value of equity. Earnings/Assets is EBITDA/total assets. R\&D is research and development expenses divided by total assets. PPE is gross property, plant and equipment divided by total assets. LnAge is the natural log of firm age as measured by the first year of available Compustat data. LTDebt Dummy is an indicator variable equal to 1 when the firm has a long-term debt rating, and 0 otherwise. STDebtDummy is an indicator variable equal to 1 when the firm has a short-term debt rating, and 0 otherwise. $\mathrm{BBB}$ is an indicator variable equal to 1 if the firm's long-term debt rating is equal to $\mathrm{BBB}+, \mathrm{BBB}$ or $\mathrm{BBB}-$. $\mathrm{BB}$ is an indicator variable equal to 1 if the firm's long-term debt rating is equal to $\mathrm{BB}+, \mathrm{BB}$ or $\mathrm{BB}-$. $\mathrm{B}$ is an indicator variable equal to 1 if the firm's long-term debt rating is equal to B+, B or B-. Below B is an indicator variable equal to 1 if the firm's long-term debt rating is below B-. Fin46 is an indicator variable equal to one for years following the adoption of FINA46, an accounting standard that changed the rules regarding the consolidation of securitization facilities.

\begin{tabular}{|c|c|c|c|c|c|}
\hline \multicolumn{6}{|c|}{ Full Sample All Firm Years $\quad N=51,737$} \\
\hline Variables & Mean & Median & Std. Deviation & $\underset{\mathrm{m}}{\operatorname{Minimu}}$ & Maximum \\
\hline Trade Receivables & 0.15594 & 0.13674 & 0.11332 & 0.00000 & 0.66160 \\
\hline Days Receivables & 61.23000 & 55.21000 & 44.32000 & 0.43869 & 601.93350 \\
\hline Payables & 0.09372 & 0.07114 & 0.08288 & 0.00000 & 1.57957 \\
\hline Leverage & 0.23290 & 0.07030 & 0.08198 & 0.00000 & 0.99939 \\
\hline Sales Growth & 0.09798 & 0.06686 & 0.30314 & -1.00000 & 1.03100 \\
\hline Turnover & 29.60827 & 8.86905 & 64.10704 & 0.18600 & 461.22220 \\
\hline Amtrecta & 0.00039 & 0.00000 & 0.00235 & 0.00000 & 0.01504 \\
\hline InTotal Assets & 6.13216 & 6.00225 & 2.11078 & 2.30299 & $\begin{array}{r}13.58957 \\
797,769.0000\end{array}$ \\
\hline Total Assets & $4,672.20400$ & 404.33900 & $20,934.69000$ & 10.00400 & 0 \\
\hline Market-to-Book & 2.50213 & 1.59147 & 3.73400 & 0.00000 & 38.24615 \\
\hline Earnings/Assets & 0.08883 & 0.11216 & 0.16717 & -3.54503 & 0.43877 \\
\hline$R \& D$ & 0.03768 & 0.00000 & 0.08010 & 0.00000 & 1.13982 \\
\hline$P P E$ & 0.57589 & 0.49020 & 0.40607 & 0.00000 & 2.35624 \\
\hline LnAge & 2.76470 & 2.39780 & 2.64250 & 0.00000 & 4.11087 \\
\hline Age & 15.87470 & 11.00000 & 14.04900 & 0.00000 & 61.00000 \\
\hline LTDebtDummy & 0.29798 & 0.00000 & 0.45737 & 0.00000 & 1.00000 \\
\hline STDebtDummy & 0.08927 & 0.00000 & 0.28514 & 0.00000 & 1.00000 \\
\hline$B B B$ & 0.08264 & 0.00000 & 0.27533 & 0.00000 & 1.00000 \\
\hline$B B$ & 0.07602 & 0.00000 & 0.26503 & 0.00000 & 1.00000 \\
\hline$B$ & 0.05996 & 0.00000 & 0.23740 & 0.00000 & 1.00000 \\
\hline Below B & 0.61814 & 1.00000 & 0.48585 & 0.00000 & 1.00000 \\
\hline
\end{tabular}




\section{TABLE 2 \\ DESCRIPTIVE STATISTICS SPLIT SAMPLES}

This table provides summary statistics for the split samples used in our analysis. All variables are defined in Table 1 . Statistics for securitization firm years are shown in Panel A. Firms that securitize receivables through a consolidated or unconsolidated SPE are classified as securitization firms. Non-securitizing firm years statistics are shown in Panel B. Panel C provides summary statistics for Trade Credit firm years. Firms offering either services or differentiated goods are classified as Trade Credit firms. Summary statistics for Non-Trade Credit firm years are shown in Panel D.

\begin{tabular}{|c|c|c|c|c|c|}
\hline \multicolumn{6}{|c|}{ Panel A: Securitizing Firm Years (1,672 firm year observations) } \\
\hline Variables & Mean & Median & Std. Deviation & Minimum & Maximum \\
\hline Trade Receivables & 0.20838 & 0.17469 & 0.13372 & 0.00000 & 0.66160 \\
\hline Days Receivables & 70.75910 & 48.93213 & 84.70324 & 3.73277 & 601.93350 \\
\hline Payables & 0.12385 & 0.09316 & 0.10163 & 0.00343 & 0.67119 \\
\hline Leverage & 0.31458 & 0.30353 & 0.16356 & 0.00000 & 0.91166 \\
\hline Sales Growth & 0.06915 & 0.05315 & 2.25487 & -0.83948 & 0.21090 \\
\hline Turnover & 19.36461 & 8.74530 & 41.75742 & 2.11035 & 461.22220 \\
\hline Amtrecta & 0.01084 & 0.00000 & 0.00634 & 0.00000 & 0.01504 \\
\hline lnAssets & 8.13793 & 8.05773 & 1.52135 & 3.52271 & 13.58957 \\
\hline Total Assets & $15,822.64000$ & $3,158.10000$ & $63,833.71000$ & 33.87600 & $797,769.00000$ \\
\hline Market-to-Book & 2.10035 & 1.42781 & 3.36240 & 0.00000 & 38.24615 \\
\hline Earnings/Assets & 0.11787 & 0.11381 & 0.06245 & -0.18705 & 0.43877 \\
\hline$R \& D$ & 0.01267 & 0.00067 & 0.02290 & 0.00000 & 0.24197 \\
\hline$P P E$ & 0.53685 & 0.47231 & 0.33485 & 0.00134 & 2.18305 \\
\hline LnAge & 2.98361 & 3.09104 & 0.89259 & 0.00000 & 4.09435 \\
\hline Age & 28.56075 & 24.00000 & 18.43326 & 2.00000 & 60.00000 \\
\hline LTDebtDummy & 0.78602 & 1.00000 & 0.41022 & 0.00000 & 1.00000 \\
\hline STDebtDummy & 0.26183 & 0.00000 & 0.43975 & 0.00000 & 1.00000 \\
\hline$B B B$ & 0.30753 & 0.00000 & 0.46159 & 0.00000 & 1.00000 \\
\hline$B B$ & 0.24409 & 0.00000 & 0.42966 & 0.00000 & 1.00000 \\
\hline$B$ & 0.11171 & 0.00000 & 0.31510 & 0.00000 & 1.00000 \\
\hline Below B & 0.21613 & 0.00000 & 0.41171 & 0.00000 & 1.00000 \\
\hline
\end{tabular}




\begin{tabular}{|c|c|c|c|c|c|}
\hline \multicolumn{6}{|c|}{ Panel B: Non-Securitizing Firm Years (50,065 firm year observations) } \\
\hline Variables & Mean & Median & Std. Deviation & Minimum & Maximum \\
\hline Trade Receivables & 0.1540 & 0.1357 & 0.1114 & 0.0000 & 0.6616 \\
\hline Days Receivables & 61.0097 & 55.3758 & 43.3080 & 0.4387 & 272.9204 \\
\hline Payables & 0.0907 & 0.0697 & 0.0780 & 0.0000 & 0.9110 \\
\hline Leverage & 0.2255 & 0.2011 & 0.1961 & 0.0000 & 0.9512 \\
\hline Sales Growth & 0.1059 & 0.0717 & 0.2798 & -1.0000 & 1.0310 \\
\hline Turnover & 29.5309 & 8.7889 & 64.2477 & 0.1860 & 461.2222 \\
\hline Amtrecta & 0.0000 & 0.0000 & 0.0000 & 0.0000 & 0.0000 \\
\hline lnAssets & 6.0999 & 5.9524 & 2.0913 & 2.3030 & 12.9198 \\
\hline Total Assets & $4,391.1970$ & 384.6830 & $17,657.9700$ & 10.0040 & $408,296.6000$ \\
\hline Market-to-Book & 2.4896 & 1.5741 & 3.7443 & 0.0000 & 38.2462 \\
\hline Earnings/Assets & 0.0936 & 0.1135 & 0.1536 & -2.2247 & 0.4388 \\
\hline$R \& D$ & 0.0375 & 0.0000 & 0.0766 & 0.0000 & 1.1398 \\
\hline$P P E$ & 0.5724 & 0.4860 & 0.4045 & 0.0000 & 2.3562 \\
\hline LnAge & 2.2054 & 2.3026 & 1.0731 & 0.0000 & 4.1109 \\
\hline Age & 18.4490 & 14.0000 & 13.6873 & 2.0000 & 61.0000 \\
\hline LTDebtDummy & 0.2779 & 0.0000 & 0.4480 & 0.0000 & 1.0000 \\
\hline STDebtDummy & 0.0856 & 0.0000 & 0.2798 & 0.0000 & 1.0000 \\
\hline$B B B$ & 0.0769 & 0.0000 & 0.2665 & 0.0000 & 1.0000 \\
\hline$B B$ & 0.0705 & 0.0000 & 0.2560 & 0.0000 & 1.0000 \\
\hline$B$ & 0.0582 & 0.0000 & 0.2341 & 0.0000 & 1.0000 \\
\hline Below B & 0.6281 & 1.0000 & 0.4833 & 0.0000 & 1.0000 \\
\hline
\end{tabular}

\begin{tabular}{|lccccc|}
\hline \multicolumn{1}{|c|}{ Panel C: Trade Credit Firm Years } & $\boldsymbol{N}=\mathbf{3 0 , 3 2 6}$ \\
\hline \multicolumn{1}{|c|}{ Variables } & Mean & Median & Std. Deviation & Minimum & Maximum \\
\hline Trade Receivables & 0.17098 & 0.15537 & 0.11724 & 0.00000 & 0.66160 \\
Days Receivables & 61.54528 & 57.02468 & 40.90134 & 0.4387 & 601.93350 \\
Payables & 0.09984 & 0.07541 & 0.08592 & 0.00000 & 0.91103 \\
Leverage & 0.21237 & 0.18761 & 0.19081 & 0.00000 & 0.93581 \\
Sales Growth & 0.09993 & 0.06852 & 0.27290 & -1.00000 & 1.03105 \\
Turnover & 30.33834 & 8.33432 & 68.80403 & 0.18600 & 461.22220 \\
Amtrecta & 0.00045 & 0.00000 & 0.00253 & 0.00000 & 0.01504 \\
lnAssets & 5.97513 & 5.80868 & 2.05317 & 2.30299 & 13.08138 \\
Total Assets & $3,844.59200$ & 333.17750 & $16,895.85000$ & 10.00400 & $479,921.00000$ \\
Market-to-Book & 2.49016 & 1.61088 & 3.66540 & 0.00000 & 38.24615 \\
Earnings/Assets & 0.09015 & 0.11012 & 0.14923 & -2.22475 & 0.43877 \\
R\&D & 0.04353 & 0.00711 & 0.07502 & 0.00000 & 1.13982 \\
PPE & 0.50902 & 0.41856 & 0.36802 & 0.00000 & 2.35624 \\
LnAge & 2.53607 & 2.48491 & 0.81013 & 0.00000 & 4.09435 \\
Age & 18.41842 & 14.00000 & 13.63349 & 2.00000 & 60.00000 \\
LTDebtDummy & 0.29328 & 0.00000 & 0.45527 & 0.00000 & 1.00000 \\
STDebtDummy & 0.08442 & 0.00000 & 0.27802 & 0.00000 & 1.00000 \\
BBB & 0.07947 & 0.00000 & 0.27048 & 0.00000 & 1.00000 \\
BB & 0.07947 & 0.00000 & 0.27048 & 0.00000 & 1.00000 \\
B & 0.06302 & 0.00000 & 0.24299 & 0.00000 & 1.00000 \\
Below B & 0.71299 & 1.00000 & 0.45238 & 0.00000 & 1.00000 \\
\hline
\end{tabular}




\begin{tabular}{|lccccc|}
\hline \multicolumn{7}{|c|}{ Panel D: Non-Trade Credit Firm Years } & N=21,411 & & & \\
\hline \multicolumn{1}{|c|}{ Variables } & Mean & Median & Std. Deviation & Minimum & Maximum \\
\hline Trade Receivables & 0.13468 & 0.11680 & 0.10239 & 0.00000 & 0.66160 \\
Days Receivables & 61.05303 & 53.43056 & 47.63370 & 0.78702 & 312.62390 \\
Payables & 0.08074 & 0.06462 & 0.06711 & 0.00000 & 0.80232 \\
Leverage & 0.23343 & 0.22095 & 0.18576 & 0.00000 & 0.95123 \\
Sales Growth & 0.11431 & 0.07557 & 0.28886 & -1.00000 & 1.03105 \\
Turnover & 27.50401 & 9.52850 & 55.37196 & 0.18600 & 461.22220 \\
Amtrecta & 0.00030 & 0.00000 & 0.00207 & 0.00000 & 0.01504 \\
lnAssets & 6.45355 & 6.39709 & 2.15236 & 2.30329 & 13.58957 \\
Total Assets & $6,158.45900$ & 600.09500 & $26,146.51000$ & 10.00700 & $797,769.00000$ \\
Market-to-Book & 2.51469 & 1.56487 & 3.80470 & 0.00000 & 38.24615 \\
Earnings/Assets & 0.10071 & 0.11839 & 0.15396 & -2.19026 & 0.43877 \\
R\&D & 0.02670 & 0.00000 & 0.07512 & 0.00000 & 1.13982 \\
PPE & 0.65906 & 0.60345 & 0.43135 & 0.00000 & 2.35624 \\
LnAge & 1.96261 & 2.07944 & 1.19766 & 0.00000 & 4.11087 \\
Age & 19.61971 & 14.00000 & 14.72101 & 2.00000 & 61.00000 \\
LTDebtDummy & 0.30027 & 0.00000 & 0.45838 & 0.00000 & 1.00000 \\
STDebtDummy & 0.10256 & 0.00000 & 0.30340 & 0.00000 & 1.00000 \\
BBB & 0.09332 & 0.00000 & 0.29088 & 0.00000 & 1.00000 \\
BB & 0.07291 & 0.00000 & 0.25999 & 0.00000 & 1.00000 \\
B & 0.05595 & 0.00000 & 0.22982 & 0.00000 & 1.00000 \\
Below B & 0.47209 & 0.00000 & 0.49923 & 0.00000 & 1.00000 \\
\hline
\end{tabular}

Consistent with Lemmon et al (2014) we find that, on average, securitizing firms are larger in size, older, have more accounts receivables as a percentage of total assets, and a larger proportion of BBB and $\mathrm{BB}$ bond ratings. We also find lower sales growth rates and higher days receivables for securitizing firms. Panels C and D display differences between TC and Non-TC firms. Specifically, TC firms are, on average, smaller in size and have more trade receivables as a percentage of total assets than Non-TC firms. T-tests confirm these differences to be statistically significant. Additionally, it is important to understand why Amtrecta has a median value of 0 . Although firms have access to securitization facilities, many report zero utilization of the facilities in their 10-k.

Table 3 provides a breakdown of the number of firms utilizing a securitization facility, and shows that the percentage of SPEs consolidated with the firm's financial statements has increased from 16\% in 1996 to $66 \%$ in 2010 . This reflects the impact of changes in FASB regulations that have put more pressure on securitizing firms to include SPEs in their consolidated financial statements. The percentage of TC firms has declined from 74\% to 62\% between 1996 and 2010 . 
TABLE 3

SECURITIZATION USE THROUGH TIME

Table 3 provides a breakdown of firm-years utilizing a securitization facility by year. Additionally, it lists the percentage of SPEs that are consolidated with the firm's financial statement and the percentage of securitization facilities established by firms offering either services or differentiated goods (classified as Trade Credit firms)

\begin{tabular}{|cccc|}
\hline Year & $\begin{array}{c}\text { \# of Securitization } \\
\text { Facilities }\end{array}$ & \% Consolidated & $\begin{array}{c}\text { Trade Credit } \\
\text { Firms }\end{array}$ \\
\hline 1996 & 82 & 16 & 74 \\
1997 & 103 & 18 & 74 \\
1998 & 124 & 19 & 70 \\
1999 & 134 & 17 & 68 \\
2000 & 161 & 18 & 68 \\
2001 & 211 & 24 & 68 \\
2002 & 215 & 27 & 67 \\
2003 & 210 & 31 & 66 \\
2004 & 197 & 32 & 69 \\
2005 & 184 & 36 & 68 \\
2006 & 179 & 35 & 66 \\
2007 & 158 & 50 & 63 \\
2008 & 158 & 55 & 63 \\
2009 & 148 & 60 & 60 \\
2010 & 115 & 66 & 62 \\
\hline
\end{tabular}

\section{REGRESSION ANALYSIS AND EMPIRICAL RESULTS}

\section{The Effect of Securitization on Trade Receivables Regression Analysis}

We estimate equation (1) using a fixed effects model. The regression includes year and industry dummy variables, as well as standard errors adjusted for within-firm clustering. Results of the regression are shown in Table 4. 
TABLE 4

THE EFFECT OF SECURITIZATION ON TRADE RECEIVABLES - FIXED EFFECTS REGRESSION

This table presents firm fixed effects regressions with Days receivables as the dependent variable. Days Receivables is measured as the ratio of trade receivables to daily sales. The independent variables include Financial Distress, an indicator variable equal to one if the firm is in financial distress according to the Asquith, Gertner and Scharfstein (1990) definition. Payables is accounts payables as a percentage of total assets. Leverage is the book value of debt divided by total assets. Sales Growth is the growth in firm sales. Turnover is Inventory Turnover, computed as cost of goods sold divided by inventory. Amtrecta is the total amount of money received for securitized receivables as a percentage of total assets. LnAssets is the natural log of total assets. Market-to-Book is the ratio of the market value to book value of equity. Earnings/Assets is EBITDA/total assets. $R \& D$ is research and development expenses divided by total assets. PPE is gross property, plant and equipment divided by total assets. LnAge is the natural log of firm age as measured by the first year of available Compustat data. LTDebt Dummy is an indicator variable equal to 1 when the firm has a long-term debt rating, and 0 otherwise. STDebtDummy is an indicator variable equal to 1 when the firm has a short-term debt rating, and 0 otherwise. $B B B$ is an indicator variable equal to 1 if the firm's long-term debt rating is equal to $\mathrm{BBB}+, \mathrm{BBB}$ or $\mathrm{BBB}-. B B$ is an indicator variable equal to 1 if the firm's long-term debt rating is equal to BB+, BB or BB-. $B$ is an indicator variable equal to 1 if the firm's longterm debt rating is equal to $\mathrm{B}+, \mathrm{B}$ or B-. Below $B$ is an indicator variable equal to 1 if the firm's long-term debt rating is below B-. Fin46 is an indicator variable equal to one for years following the adoption of FINA46, an accounting standard that changed the rules regarding the consolidation of securitization facilities. The regression includes year and industry dummy variables as well as standard errors adjusted for within-firm clustering. T-statistics appear in parenthesis under the coefficient estimates. ${ }^{*},{ }^{* *}$ and $* * *$ identify estimates that are statistically significant at $10 \%, 5 \%$ and $1 \%$ levels, respectively.

\begin{tabular}{|c|c|c|c|c|c|c|}
\hline \multirow[b]{2}{*}{ Variables } & \multicolumn{2}{|c|}{$\begin{array}{c}\text { Model 1 } \\
\text { Full Sample } \\
\end{array}$} & \multicolumn{2}{|c|}{$\begin{array}{c}\text { Model 2 } \\
\text { Trade Credit Firm Years } \\
\end{array}$} & \multicolumn{2}{|c|}{\begin{tabular}{|c|} 
Model 3 \\
Non-Trade Credit Firm Years
\end{tabular}} \\
\hline & Coefficient & Std. Error & Coefficient & Std. Error & Coefficient & Std. Error \\
\hline Financial Distress $_{t-1}$ & $\begin{array}{l}-1.32028 \\
(-2.17)^{* *}\end{array}$ & 0.66082 & $\begin{array}{l}-1.26298 \\
(-1.75)^{*}\end{array}$ & 0.72325 & $\begin{array}{c}-0.56542 \\
(-0.50)\end{array}$ & 1.12275 \\
\hline Payables $_{t-1}$ & $\begin{array}{l}16.62104 \\
(2.07)^{* *} \\
\end{array}$ & 8.01511 & $\begin{array}{l}19.61841 \\
(2.50)^{* *} \\
\end{array}$ & 0.02515 & $\begin{array}{c}25.56094 \\
(1.48) \\
\end{array}$ & 17.32224 \\
\hline Leverage $_{t-1}$ & $\begin{array}{l}11.87186 \\
(6.06)^{* * *}\end{array}$ & 1.95820 & $\begin{array}{l}10.28274 \\
(4.61)^{* * *}\end{array}$ & 2.23216 & $\begin{array}{l}10.02130 \\
(3.05)^{* * *}\end{array}$ & 3.28457 \\
\hline Sales Growth ${ }_{t-1}$ & $\begin{array}{c}-0.00431 \\
(-1.52) \\
\end{array}$ & 0.00283 & $\begin{array}{l}-0.00509 \\
(3.35)^{* * *}\end{array}$ & 0.00152 & $\begin{array}{c}-0.05634 \\
(-0.26) \\
\end{array}$ & 0.21557 \\
\hline Turnover $_{t-1}$ & $\begin{array}{c}-0.03225 \\
(-5.96)^{* * *} \\
\end{array}$ & 0.00541 & $\begin{array}{c}-0.02299 \\
(-3.20) * * *\end{array}$ & 0.00717 & $\begin{array}{c}-0.04542 \\
(-5.02)^{* * *}\end{array}$ & 0.00906 \\
\hline Amtrecta $_{t-1}$ & $\begin{array}{r}55.30777 \\
(4.17)^{* * *} \\
\end{array}$ & 13.27488 & $\begin{array}{l}48.55610 \\
(4.03)^{* * *} \\
\end{array}$ & 12.05937 & $\begin{array}{c}4.80376 \\
(0.24) \\
\end{array}$ & 19.97132 \\
\hline LnAssets $_{t-1}$ & $\begin{array}{c}-1.62297 \\
(-3.75)^{* * *} \\
\end{array}$ & 0.43302 & $\begin{array}{r}1.28370 \\
(1.97)^{* *} \\
\end{array}$ & 0.65215 & $\begin{array}{l}-1.64277 \\
(-2.38)^{* *} \\
\end{array}$ & 0.68983 \\
\hline Market-to-Book ${ }_{t-1}$ & $\begin{array}{l}0.10261 \\
(1.76)^{*} \\
\end{array}$ & 0.05830 & $\begin{array}{c}0.08497 \\
(1.37) \\
\end{array}$ & 0.06223 & $\begin{array}{c}0.06578 \\
(0.62) \\
\end{array}$ & 0.10635 \\
\hline Earnings/Assets $_{t-1}$ & $\begin{array}{c}-26.04128 \\
(-11.68) * * * \\
\end{array}$ & 2.22879 & $\begin{array}{l}-23.10395 \\
(-9.81)^{* * *}\end{array}$ & 2.35571 & $\begin{array}{l}-33.23289 \\
(-7.94)^{* * *} \\
\end{array}$ & 4.18298 \\
\hline$R \& D_{t-1}$ & $\begin{array}{l}-27.80438 \\
(-3.53)^{* * *}\end{array}$ & 7.87137 & $\begin{array}{l}-26.78520 \\
(-3.25)^{* * *} \\
\end{array}$ & 8.23887 & $\begin{array}{c}-18.11878 \\
(-1.17) \\
\end{array}$ & 15.49725 \\
\hline$P P E_{t-1}$ & $\begin{array}{c}-21.27132 \\
(-14.74)^{* * *}\end{array}$ & 1.44305 & $\begin{array}{l}-16.10565 \\
(-8.82) * * *\end{array}$ & 1.82607 & $\begin{array}{c}-23.45244 \\
(-10.03)^{* * *}\end{array}$ & 2.33817 \\
\hline LnAge $t-1$ & $\begin{array}{c}-0.95210 \\
(-3.54)^{* * *}\end{array}$ & 0.26858 & $\begin{array}{c}-8.12580 \\
(-10.20)^{* * *}\end{array}$ & 0.79633 & $\begin{array}{c}0.03411 \\
(0.08) \\
\end{array}$ & 0.41192 \\
\hline LTDebtDummy $_{t-1}$ & $\begin{array}{c}4.01970 \\
(3.37)^{* * *}\end{array}$ & 1.19221 & $\begin{array}{c}-2.07516 \\
(-0.75) \\
\end{array}$ & 2.75032 & $\begin{array}{r}1.00357 \\
(0.62) \\
\end{array}$ & 1.62881 \\
\hline STDebtDummy $_{t-1}$ & $\begin{array}{l}2.14201 \\
(1.73)^{*}\end{array}$ & 1.23533 & $\begin{array}{c}2.24823 \\
(1.38) \\
\end{array}$ & 1.62923 & $\begin{array}{c}1.09348 \\
(0.58) \\
\end{array}$ & 1.88993 \\
\hline$B B B_{t-1}$ & $\begin{array}{l}-1.73456 \\
(-1.86)^{*} \\
\end{array}$ & 0.93424 & $\begin{array}{r}-3.40143 \\
(-2.32)^{* *} \\
\end{array}$ & 1.46486 & $\begin{array}{c}-1.27524 \\
(-0.92) \\
\end{array}$ & 1.39331 \\
\hline$B B_{t-1}$ & $\begin{array}{c}-3.50183 \\
(-3.11)^{* * *} \\
\end{array}$ & 1.12732 & $\begin{array}{c}-7.09162 \\
(-3.54)^{* * *}\end{array}$ & 2.00115 & $\begin{array}{c}-2.03711 \\
(-1.32) \\
\end{array}$ & 1.53858 \\
\hline$B_{t-1}$ & $\begin{array}{c}-3.62571 \\
(-3.03)^{* * *}\end{array}$ & 1.19486 & $\begin{array}{c}-7.75883 \\
(-3.55) * * *\end{array}$ & 2.18517 & $\begin{array}{c}-1.05040 \\
(-0.62) \\
\end{array}$ & 1.68345 \\
\hline Below $B_{t-1}$ & $\begin{array}{c}2.33516 \\
(3.18)^{* * *}\end{array}$ & 0.73368 & $\begin{array}{l}-6.80280 \\
(-2.12)^{* *}\end{array}$ & 3.20465 & $\begin{array}{c}0.44342 \\
(0.35)\end{array}$ & 1.26918 \\
\hline
\end{tabular}


Results for the full sample show that increases in securitization (as measured by Amtrecta) are significantly positively associated with increases in days receivables. This is consistent with our prediction that firms use securitization as a means of providing liquidity to enable the extension of additional trade credit. This is in contrast to the findings of Lemmon et al (2014), who use an event study framework to analyze receivables prior to the initiation of a securitization facility and in the year following the initiation of the facility. They do not see any increase in the total amount of receivables financed in the year following the initiation of a securitization facility. Instead, they conclude that securitization proceeds in the year following the initiation of a securitization facility are largely used to pay down existing debt. This difference in results is likely due to methodology differences. Our method examines all securitization activity from 1996 to 2010, whereas Lemmon et al focus on changes surrounding the initiation of a securitization facility in an event study framework.

In split sample analysis, we find that Amtrecta is positively associated with trade receivables for TC firms, but is not significant for Non-TC firms. This result supports the idea that trade credit benefits of securitization are most recognized among firms that place the highest value on trade credit. As expected, an increase in financial distress is associated with a decrease in trade receivables in the full sample. Firms in distress lack liquidity and are less able to wait for payment from buyers, so firms in financial distress offer less trade financing to buyers, other things equal.

In the split sample analysis, the coefficient on the financial distress variable remains negative for TC firms, but for Non-TC firms it is not significant. Firm size is positive and significant for the TC sample, but negative in the Non-TC sample. Payables is also positive and significant in the TC sample, but is not significant in the Non-TC sample. We believe these differences are consistent with the standard determinants of trade credit policy having a positive and significant impact among firms that value trade credit more highly. We additionally see that access to debt, proxied by long-term and short-term debt ratings, is positively significantly related to trade credit policy for the full sample, indicating access to credit is positively related to the extension of trade credit. Also $R \& D$, which is positively associated with trade receivables in the full sample and the TC firm years split sample, is negative in the Non-TC firm years split sample.

To mitigate possible endogeneity concerns, we re-estimate equation (1) using two-stage least squares (2SLS). In the first stage, we use Amtrecta as the dependent variable and use Fin46 as an instrumental variable. Fin 46 is an indicator variable equal to one for years following the adoption of the Fin 46 accounting standard. This standard changed the accounting rules regarding consolidation of securitization facilities. Changes in securitization accounting standards should be relevant in determining a firm's level of securitization, but should not affect the firm's trade receivables policy except through the effect on Amtrecta, so Fin46 should satisfy the instrumental variable criterion. In the second stage, we use the predicted value for Amtrecta and test for its effect on the firm's trade receivables. Results of the 2SLS regression for equation (1) are presented in Table 5. 
TABLE 5

THE EFFECT OF SECURITIZATION ON TRADE RECEIVABLES - 2SLS REGRESSIONS

This table presents two stage least squares regressions with Days receivables as the dependent variable. Days Receivables is measured as the ratio of trade receivables to daily sales. The independent variables include Financial Distress, an indicator variable equal to one if the firm is in financial distress according to the Asquith, Gertner and Scharfstein (1990) definition. Payables is accounts payables as a percentage of total assets. Leverage is the book value of debt divided by total assets. Sales Growth is the growth in firm sales. Turnover is Inventory Turnover, computed as cost of goods sold divided by inventory. Amtrecta is the total amount of money received for securitized receivables as a percentage of total assets. LnTotal Assets is the natural log of total assets. Market-toBook is the ratio of the market value to book value of equity. Earnings/Assets is EBITDA/total assets. $R \& D$ is research and development expenses divided by total assets. PPE is gross property, plant and equipment divided by total assets. LnAge is the natural log of firm age as measured by the first year of available Compustat data. LTDebt Dummy is an indicator variable equal to 1 when the firm has a long-term debt rating, and 0 otherwise. STDebtDummy is an indicator variable equal to 1 when the firm has a shortterm debt rating, and 0 otherwise. $B B B$ is an indicator variable equal to 1 if the firm's long-term debt rating is equal to $\mathrm{BBB}+, \mathrm{BBB}$ or BBB-. $B B$ is an indicator variable equal to 1 if the firm's long-term debt rating is equal to BB+, BB or BB-. $B$ is an indicatorvariable equal to 1 if the firm's long-term debt rating is equal to $\mathrm{B}+$, $\mathrm{B}$ or B-. Below $B$ is an indicator variable equal to 1 if the firm's long-term debt rating is below B-. The regression includes year and industry dummy variables as well as standard errors adjusted for within-firm clustering. T-statistics appear in parenthesis under the coefficient estimates. $*, * *$ and $* * *$ identify estimates that are statistically significant at $10 \%, 5 \%$ and $1 \%$ levels, respectively.

\begin{tabular}{|c|c|c|c|c|c|c|}
\hline \multirow[b]{2}{*}{ Variables } & \multicolumn{2}{|c|}{$\begin{array}{c}\text { Model 1 } \\
\text { Full Sample }\end{array}$} & \multicolumn{2}{|c|}{$\begin{array}{c}\text { Model 2 } \\
\text { Trade Credit Firm Years } \\
\end{array}$} & \multicolumn{2}{|c|}{$\begin{array}{c}\text { Model 3 } \\
\text { Non-Trade Credit Firm Years }\end{array}$} \\
\hline & Coefficient & Std. Error & Coefficient & Std. Error & Coefficient & Std. Error \\
\hline Financial Distress $_{t-1}$ & $\begin{array}{c}10.95358 \\
(1.28) \\
\end{array}$ & 8.58341 & $\begin{array}{l}3.3299 \\
(0.365) \\
\end{array}$ & 3.6777 & $\begin{array}{c}-21.5381 \\
(-0.70) \\
\end{array}$ & 30.6378 \\
\hline Payables $_{t-1}$ & $\begin{array}{c}-11.70570 \\
(-1.81)^{*} \\
\end{array}$ & 16.70390 & $\begin{array}{c}-14.5461 \\
(-3.27)^{* * *} \\
\end{array}$ & 4.2462 & $\begin{array}{r}23.0442 \\
(0.452) \\
\end{array}$ & 12.8111 \\
\hline Leverage $_{t-1}$ & $\begin{array}{l}-13.47828 \\
(-1.76)^{*} \\
\end{array}$ & 7.66355 & $\begin{array}{c}6.9715 \\
(1.36) \\
\end{array}$ & 5.1324 & $\begin{array}{c}31.9614 \\
(0.60)\end{array}$ & 53.2209 \\
\hline Sales Growth ${ }_{t-1}$ & $\begin{array}{c}0.00034 \\
(0.02)\end{array}$ & 0.02125 & $\begin{array}{l}0.0047 \\
(0.909)\end{array}$ & 0.0047 & $\begin{array}{c}-0.2664 \\
(-0.16)\end{array}$ & 1.6529 \\
\hline Turnover $_{t-1}$ & $\begin{array}{c}-0.00385 \\
(-0.18) \\
\end{array}$ & 0.02180 & $\begin{array}{l}0.0158 \\
(1.10) \\
\end{array}$ & 0.0144 & $\begin{array}{r}-0.0843 \\
(-0.73) \\
\end{array}$ & 0.1149 \\
\hline Amtrecta $_{t-1}$ & $\begin{array}{l}46.79000 \\
(2.25)^{* *}\end{array}$ & 31.02400 & $\begin{array}{l}37.6286 \\
(2.13)^{* *}\end{array}$ & 17.6945 & $\begin{array}{c}-27.0430 \\
(-0.73) \\
\end{array}$ & 36.4038 \\
\hline LnAssets $_{t-1}$ & $\begin{array}{l}-6.14789 \\
(-2.18)^{* *} \\
\end{array}$ & 2.82372 & $\begin{array}{l}-5.57586 \\
(-2.14)^{* *} \\
\end{array}$ & 2.60503 & $\begin{array}{c}6.56644 \\
(0.79) \\
\end{array}$ & 8.33211 \\
\hline Market-to-Book $k_{t-1}$ & $\begin{array}{c}-0.05250 \\
(-0.19) \\
\end{array}$ & 0.27576 & $\begin{array}{c}-0.01748 \\
(-0.07) \\
\end{array}$ & 0.23950 & $\begin{array}{c}0.99522 \\
(0.66) \\
\end{array}$ & 1.50146 \\
\hline Earnings/Assets $_{t-1}$ & $\begin{array}{c}-10.87961 \\
(-0.96) \\
\end{array}$ & 11.29226 & $\begin{array}{c}-14.83898 \\
(-1.70)^{*}\end{array}$ & 8.71277 & $\begin{array}{c}-85.02060 \\
(-1.07) \\
\end{array}$ & 79.26573 \\
\hline$R \& D_{t-1}$ & $\begin{array}{l}104.17900 \\
(3.53)^{* * *}\end{array}$ & 29.48665 & $\begin{array}{l}100.38510 \\
(4.00) * * *\end{array}$ & 25.11510 & $\begin{array}{c}-72.03100 \\
(-0.47) \\
\end{array}$ & 154.54770 \\
\hline$P P E_{t-1}$ & $\begin{array}{c}-0.91888 \\
(-0.11) \\
\end{array}$ & 8.39346 & $\begin{array}{c}-9.33194 \\
(-1.43) \\
\end{array}$ & 6.51250 & $\begin{array}{c}-40.47750 \\
(-1.17) \\
\end{array}$ & 34.59379 \\
\hline $\operatorname{LnAge}_{t-1}$ & $\begin{array}{l}-4.66636 \\
(-2.25)^{* *}\end{array}$ & 2.07129 & $\begin{array}{l}-3.00045 \\
(-1.74)^{*} \\
\end{array}$ & 1.72850 & $\begin{array}{c}5.65018 \\
(0.53)\end{array}$ & 10.75112 \\
\hline LTDebtDummy $_{t-1}$ & $\begin{array}{c}1.77724 \\
(0.27)\end{array}$ & 6.56118 & $\begin{array}{c}1.98920 \\
(0.33)\end{array}$ & 5.99950 & $\begin{array}{c}-20.65403 \\
(-0.49) \\
\end{array}$ & 41.90623 \\
\hline STDebtDummy $_{t-1}$ & $\begin{array}{l}22.66856 \\
(2.13)^{* *}\end{array}$ & 10.61766 & $\begin{array}{l}20.85379 \\
(2.32)^{* *}\end{array}$ & 2.32000 & $\begin{array}{c}-22.05796 \\
(-0.66) \\
\end{array}$ & 33.44480 \\
\hline$B B B_{t-1}$ & $\begin{array}{c}-7.68297 \\
(-1.42) \\
\end{array}$ & 5.41894 & $\begin{array}{c}-6.50410 \\
(-1.19) \\
\end{array}$ & 5.45840 & $\begin{array}{c}42.27216 \\
(0.66) \\
\end{array}$ & 63.65118 \\
\hline$B B_{t-1}$ & $\begin{array}{l}-22.98440 \\
(-3.19) * * *\end{array}$ & 7.21511 & $\begin{array}{l}-20.95345 \\
(-3.80)^{* * *}\end{array}$ & 5.51940 & $\begin{array}{c}49.88016 \\
(0.60)\end{array}$ & 83.03339 \\
\hline$B_{t-1}$ & $\begin{array}{c}-33.04010 \\
(-3.50)^{* * *}\end{array}$ & 9.44439 & $\begin{array}{c}-32.69623 \\
(-4.49)^{* * *}\end{array}$ & 7.28652 & $\begin{array}{c}36.69489 \\
(0.52) \\
\end{array}$ & 70.95157 \\
\hline Below $B_{t-1}$ & $\begin{array}{l}-6.39475 \\
(-1.90)^{*} \\
\end{array}$ & 3.36608 & $\begin{array}{c}-9.16437 \\
(-2.71)^{* * *}\end{array}$ & 3.37659 & $\begin{array}{c}-25.37330 \\
(-0.71)\end{array}$ & 35.97631 \\
\hline
\end{tabular}


The impact of securitization (Amtrecta) on trade receivables remains positive and significant for the full sample. Amtrecta also remains significant at the 5\% level for TC firms, and is not significant for Non-TC firms. We also recognize the change of signs for multiple variable coefficients when compared to the results in Table 4. We believe these differences could be the result of an existing endogeneity bias that was present in the fixed effects regression of Table 4, and that controlling for this bias using 2SLS has altered the significance for some variables. However, our result for Amtrecta significance remains positive and significant, after controlling for endogeneity.

\section{The Effect of Securitization on Sales Growth Regression Analysis}

Results of the Equation (2) firm fixed effects regression are shown in Table 6. In this regression, the dependent variable is industry adjusted firm sales growth. We include industry adjusted control variables for investment, asset sales, earnings, and financial distress. After controlling for these variables, we find a positive and significant association between securitization (Amtrecta) and industry adjusted firm sales growth for the full sample. However, the statistical significance of this result in the full sample is coming entirely from the TC firms. The coefficient on Amtrecta in the TC firm split sample is positive and significant, but for the Non-TC firm sample, the coefficient on Amtrecta is negative and not significant. This result is consistent with the finding of Giannetti et al (2011) that firms producing standardized goods (in our case Non-TC firms) rely less on the use of trade credit to generate sales. Given Giannetti et al's results, we would expect TC firms (who produce services and differentiated goods) to be more likely than Non-TC firms to use securitization as a means of providing liquidity to generate additional accounts receivable in an effort to increase sales. 


\section{TABLE 6 \\ THE EFFECT OF SECURITIZATION ON SALES GROWTH}

Table 6 presents a firm fixed effects regression with AdjustedSalesGrowth (industry-adjusted firm sales growth from period $t$ - 1 to $t$ ) as the dependent variable. The independent variables include the lagged values of the natural log of sales (LnSales), industry-adjusted earnings (EBITDA) as a perentage of assets (Ind Earn/Assets), industry-adjusted investment as a percentage of assets (Ind Invest/Assets), industry-adjusted asset sales (Ind Asset Sales), an indicator variable for financial distress (Financial Distress) equal to one if the firm is in financial distress according to the Asquith, Gertner and Scharfstein (1990) definition, an indicator variable if the firm's decrease in trade receivables to assets is in the 10th percentile for the industry (Receivables Decrease), and Amtrecta, which is the total amount of money received for securitized receivables as a percentage of total assets. The regression includes year and industry indicator variables as well as standard errors adjusted for within-firm clustering. T-statistics appear in parenthesis under the coefficient estimates. $* * *$ and $* * *$ identify estimates that are statistically significant at $10 \%, 5 \%$ and $1 \%$ levels, respectively.

\begin{tabular}{|c|c|c|c|c|c|c|}
\hline \multirow[b]{2}{*}{ Variables } & \multicolumn{2}{|c|}{$\begin{array}{c}\text { Model } 1 \\
\text { Full Sample } \\
\end{array}$} & \multicolumn{2}{|c|}{$\begin{array}{c}\text { Model } 2 \\
\text { Trade Credit Firm Years } \\
\end{array}$} & \multicolumn{2}{|c|}{$\begin{array}{c}\text { Model } 3 \\
\text { Non-Trade Credit Firm Years }\end{array}$} \\
\hline & Coefficient & Std. Error & Coefficient & Std. Error & Coefficient & Std. Error \\
\hline LnSales $_{t-1}$ & $\begin{array}{c}-0.29170 \\
(-32.33)^{* * *}\end{array}$ & 0.00902 & $\begin{array}{c}-0.21448 \\
(-32.23)^{* * *} \\
\end{array}$ & 0.00666 & $\begin{array}{c}-0.15566 \\
(-30.62)^{* * *}\end{array}$ & 0.00508 \\
\hline Ind Earn/Assets ${ }_{t-1}$ & $\begin{array}{c}-0.20905 \\
(-4.63)^{* * *}\end{array}$ & 0.04514 & $\begin{array}{l}-0.06719 \\
(-2.19)^{* *} \\
\end{array}$ & 0.03072 & $\begin{array}{c}-0.12978 \\
(-3.39)^{* * *}\end{array}$ & 0.03833 \\
\hline Ind Invest/Assets ${ }_{t-1}$ & $\begin{array}{c}-0.10342 \\
(-1.53) \\
\end{array}$ & 0.06759 & $\begin{array}{c}-0.14551 \\
(-3.25) * * *\end{array}$ & 0.04478 & $\begin{array}{c}-0.00589 \\
(-0.13) \\
\end{array}$ & 0.04597 \\
\hline Ind Asset Sales ${ }_{t-1}$ & $\begin{array}{c}0.03600 \\
(0.30)\end{array}$ & 0.11926 & $\begin{array}{l}-0.08086 \\
(-0.76)\end{array}$ & 0.10693 & $\begin{array}{c}-0.01211 \\
(-0.09)\end{array}$ & 0.13872 \\
\hline Financial Distress $_{t-1}$ & $\begin{array}{l}-0.02998 \\
(-2.48)^{* *} \\
\end{array}$ & 0.01211 & $\begin{array}{c}-0.02669 \\
(-3.05) * * * \\
\end{array}$ & 0.00875 & $\begin{array}{c}-0.03775 \\
(-3.38)^{* * *} \\
\end{array}$ & 0.01117 \\
\hline Receivables Decrease $_{t-1}$ & $\begin{array}{c}0.01270 \\
(14.02)^{* * *}\end{array}$ & 0.00091 & $\begin{array}{c}0.01020 \\
(14.33)^{* * *}\end{array}$ & 0.00071 & $\begin{array}{c}0.00773 \\
(9.90)^{* * *}\end{array}$ & 0.00078 \\
\hline Amtrecta $_{t-1}$ & $\begin{array}{l}0.36232 \\
(1.80)^{*}\end{array}$ & 0.20094 & $\begin{array}{l}0.55339 \\
(2.46)^{* *}\end{array}$ & 0.22483 & $\begin{array}{c}-0.28094 \\
(-1.01)\end{array}$ & 0.27936 \\
\hline
\end{tabular}

\section{The Effect of Securitization on Market Share Regression Analysis}

Table 7 presents the results of a firm fixed effects regression using Equation (3) with firm market share as the dependent variable. The impact of the nature of the goods sold on the effect of securitization is particularly pronounced in these results. In the overall sample, securitization, as measured by Amtrecta, is not related to market share growth. However, in the split sample results, Amtrecta is positively and significantly associated with market share for TC firms. In contrast, the sign of the coefficient on Amtrecta for Non-TC firms is negative but not statistically significant, indicating no significant relation between securitization and market share for Non-TC firms. 
TABLE 7

THE EFFECT OF SECURITIZATION ON MARKET SHARE

Table 7 presents a firm fixed effects regression with firm market share change from period $t-1$ to $t$ (Market Share Change) as the dependent variable. The independent variables include the lagged values of the natural log of sales (LnSales), industry-adjusted earnings (EBITDA) as a perentage of assets (Ind Earn/Assets), industry-adjusted investment as a percentage of assets (Ind Invest/Assets), industry-adjusted asset sales (Ind Asset Sales), an indicator variable for financial distress (Financial Distress) equal to one if the firm is in financial distress according to the Asquith, Gertner and Scharfstein (1990) definition, an indicator variable if the firm's decrease in trade receivables is in the 10th percentile for the industry (Receivables Decrease), and Amtrecta, which is the total amount of money received for securitized receivables as a percentage of total assets. The regression includes year and industry indicator variables as well as standard errors adjusted for within-firm clustering. T-statistics appear in parenthesis under the coefficient estimates. ${ }^{*},{ }^{* *}$ and ${ }^{* * *}$ identify estimates that are statistically significant at $10 \%, 5 \%$ and $1 \%$ levels, respectively.

\begin{tabular}{|c|c|c|c|c|c|c|}
\hline \multirow[b]{2}{*}{ Variables } & \multicolumn{2}{|c|}{$\begin{array}{c}\text { Model } 1 \\
\text { Full Sample }\end{array}$} & \multicolumn{2}{|c|}{$\begin{array}{c}\text { Model 2 } \\
\text { Trade Credit Firm Years } \\
\end{array}$} & \multicolumn{2}{|c|}{$\begin{array}{c}\text { Model 3 } \\
\text { Non-Trade Credit Firm Years } \\
\end{array}$} \\
\hline & Coefficient & Std. Error & Coefficient & Std. Error & Coefficient & Std. Error \\
\hline LnSales $_{t-1}$ & $\begin{array}{c}-0.16438 \\
(-30.63)^{* * *}\end{array}$ & 0.00537 & $\begin{array}{c}-0.18308 \\
(23.81)^{* * *}\end{array}$ & 0.00769 & $\begin{array}{l}-0.15916 \\
(-19.31)\end{array}$ & 0.00824 \\
\hline Ind Earn/Assets ${ }_{t-1}$ & $\begin{array}{c}-0.07914 \\
(-3.17)^{* * *}\end{array}$ & 0.02494 & $\begin{array}{c}-0.07311 \\
(-2.62)^{* * *}\end{array}$ & 0.02790 & $\begin{array}{l}-0.10595 \\
(-2.20)^{* *}\end{array}$ & 0.04825 \\
\hline Ind Invest/Assets ${ }_{t-1}$ & $\begin{array}{c}0.11836 \\
(3.55)^{* * *}\end{array}$ & 0.03333 & $\begin{array}{l}0.07294 \\
(1.82)^{*}\end{array}$ & 0.04005 & $\begin{array}{l}0.12320 \\
(2.19)^{* *}\end{array}$ & 0.05638 \\
\hline Ind Asset Sales ${ }_{t-1}$ & $\begin{array}{c}0.13008 \\
(1.42)\end{array}$ & 0.09182 & $\begin{array}{c}0.10681 \\
(1.01)\end{array}$ & 0.10591 & $\begin{array}{c}0.07369 \\
(0.45)\end{array}$ & 0.16333 \\
\hline Financial Distress $s_{t-1}$ & $\begin{array}{c}-0.02293 \\
(-3.29)^{* * *}\end{array}$ & 0.00696 & $\begin{array}{l}-0.01974 \\
(-2.39)^{* *}\end{array}$ & 0.00827 & $\begin{array}{l}-0.02915 \\
(-2.29)^{* *}\end{array}$ & 0.01272 \\
\hline Receivables Decrease $_{t-1}$ & $\begin{array}{l}0.00778 \\
(13.26)\end{array}$ & 0.00059 & $\begin{array}{c}0.00761 \\
(10.49)^{* * *}\end{array}$ & 0.00073 & $\begin{array}{c}0.00618 \\
(6.27)^{* * *}\end{array}$ & 0.00099 \\
\hline Amtrecta $_{t-1}$ & $\begin{array}{c}0.00000 \\
(0.00)\end{array}$ & 0.04210 & $\begin{array}{l}0.07051 \\
(1.71)^{*}\end{array}$ & 0.04112 & $\begin{array}{c}-0.39533 \\
(-1.10)\end{array}$ & 0.12587 \\
\hline
\end{tabular}

TC firms appear more likely to use trade credit as a tool to increase sales. For these firms, securitization provides a mechanism for generating capital that can be used to invest in additional accounts receivable in an effort to buy sales. This is consistent with Giannetti et al (2011) who find that trade receivables are more important for firms that produce services or differentiated goods.

Non-TC firms do not appear to use trade receivables to increase sales or market share. Lemmon et al (2014) find that in a sample of all securitizing firms, the initiation of a securitization program is associated with a decrease in debt levels. This suggests that firms used the proceeds from securitization to pay off other (possibly more expensive) forms of debt. Our results suggest that firms that most highly value trade credit may utilize securitization facilities to increase the level of investment in trade receivables. Securitization is not associated with sales or market share growth for Non TC firms.

\section{The Effect of Securitization on Income Growth Regression Results}

Results of the equation (4) firm fixed effects regression are shown in Table 8. This regression analyzes whether securitization is associated with income growth. The dependent variable in this regression is industry-adjusted firm income growth. Results from this regression show a negative but not statistically significant relation between Amtrecta and income growth. The same result is found for the TC and Non-TC split samples, although the coefficient on Amtrecta for the TC sample is very close to 
significant (t-statistic of -1.63). These results indicate that while the use of securitization is associated with increased sales growth and improved market share for TC firms, this sales and market share growth does not translate into improved income, at least in the short term. This is consistent with Smith (1987). According to Smith, "Excess profits are not necessarily generated by the use of trade credit" (Smith (1987), p. 869). Smith's theory is that while increasing profit may lead the firm to offer trade credit, competition causes the selling firm to pass on its gains to buyers. Firms may pursue securitization even if short-term profit is not positive, if securitization allows the firm to buy additional sales and increase market share sufficiently to secure a position as a dominant participant in the industry. Using securitization as a vehicle to fund trade receivables programs may be costly in the short run, but may result in higher long-term profits if the firm is successful in increasing market share.

\section{TABLE 8 \\ THE EFFECT OF SECURITIZATION ON INCOME GROWTH}

Table 8 presents a firm fixed effects regression with industry-adjusted firm income growth (AdjustedIncomeGrowth) from period $t$ - 1 to $t$ as the dependent variable. The independent variables include the lagged values of the natural log of sales (LnSales), industryadjusted earnings (EBITDA) as a perentage of assets (Ind Earn/Assets), industry-adjusted investment as a percentage of assets (Ind Invest/Assets), industry-adjusted asset sales (Ind Asset Sales), an indicator variable for financial distress (Financial Distress) equal to one if the firm is in financial distress according to the Asquith, Gertner and Scharfstein (1990) definition, an indicator variable if the firm's decrease in trade receivables is in the 10th percentile for the industry (Receivables Decrease), and Amtrecta, which is the total amount of money received for securitized receivables as a percentage of total assets. The regression includes year and industry indicator variables as well as standard errors adjusted for within-firm clustering. T-statistics appear in parenthesis under the coefficient estimates. ${ }^{*},{ }^{* *}$ and ${ }^{* * *}$ identify estimates that are statistically significant at $10 \%, 5 \%$ and $1 \%$ levels, respectively.

\begin{tabular}{|c|c|c|c|c|c|c|}
\hline \multirow[b]{2}{*}{ Variables } & \multicolumn{2}{|c|}{$\begin{array}{c}\text { Model 1 } \\
\text { Full Sample } \\
\end{array}$} & \multicolumn{2}{|c|}{$\begin{array}{c}\text { Model 2 } \\
\text { Trade Credit Firm Years } \\
\end{array}$} & \multicolumn{2}{|c|}{$\begin{array}{c}\text { Model 3 } \\
\text { Non-Trade Credit Firm Years }\end{array}$} \\
\hline & Coefficient & Std. Error & Coefficient & Std. Error & Coefficient & Std. Error \\
\hline LnSales $_{t-1}$ & $\begin{array}{l}-0.03281 \\
(-1.74)^{*}\end{array}$ & 0.01884 & $\begin{array}{c}0.01233 \\
(0.46)\end{array}$ & 0.02652 & $\begin{array}{l}-0.05727 \\
(-2.02)^{* *}\end{array}$ & 0.02831 \\
\hline Ind Earn/Assets ${ }_{t-1}$ & $\begin{array}{c}-0.04029 \\
(-0.48) \\
\end{array}$ & 0.08437 & $\begin{array}{c}-0.16986 \\
(-1.50) \\
\end{array}$ & 0.11354 & $\begin{array}{c}0.06435 \\
(0.47)\end{array}$ & 0.13777 \\
\hline Ind Invest/Assets ${ }_{t-1}$ & $\begin{array}{l}-0.39217 \\
(-2.09)^{* *}\end{array}$ & 0.18782 & $\begin{array}{c}-0.27872 \\
(-1.07)\end{array}$ & 0.25994 & $\begin{array}{l}-0.60339 \\
(-2.11)^{* *}\end{array}$ & 0.28555 \\
\hline Ind Asset Sales ${ }_{t-1}$ & $\begin{array}{c}0.05698 \\
(-0.09) \\
\end{array}$ & 0.60510 & $\begin{array}{c}-0.26235 \\
0.35) \\
\end{array}$ & 0.74816 & $\begin{array}{c}0.55209 \\
(0.54) \\
\end{array}$ & 1.02208 \\
\hline Financial Distress $_{t-1}$ & $\begin{array}{c}-0.25571 \\
(-8.38)^{* * *}\end{array}$ & 0.03050 & $\begin{array}{c}-0.24685 \\
(-6.20) * * *\end{array}$ & 0.03982 & $\begin{array}{c}-0.26847 \\
(-5.13) * * * \\
\end{array}$ & 0.05238 \\
\hline Receivables Decrease $_{t-1}$ & $\begin{array}{l}-0.00311 \\
(-0.94) \\
\end{array}$ & 0.00329 & $\begin{array}{c}-0.00375 \\
(-0.86) \\
\end{array}$ & 0.00434 & $\begin{array}{c}-0.00072 \\
(-0.13) \\
\end{array}$ & 0.00539 \\
\hline Amtrecta $_{t-I}$ & $\begin{array}{l}-0.51486 \\
(-1.58)\end{array}$ & 0.32567 & $\begin{array}{l}-0.55720 \\
(-1.63)\end{array}$ & 0.34080 & $\begin{array}{c}-0.52170 \\
(-0.75)\end{array}$ & 0.69993 \\
\hline
\end{tabular}

\section{ROBUSTNESS CHECKS}

We reassess the regression analysis using an indicator variable instead of Amtrecta. The indicator variable is set to one if a firm securitized receivables in a particular firm year, and is set to zero otherwise. The key results for equation (1) (unreported but available upon request) are similar to the results with the Amtrecta variable. The securitization variable remains significantly positively associated with trade receivables in the full sample and in the TC firm years split sample. However, the coefficient on the 
securitization variable is positive but not significant in the Non-TC firm years split sample. Results for the sales growth regression (equation 2) are consistent with the results using Amtrecta. The securitization variable is positively associated with industry-adjusted firm sales growth, but this result is coming entirely from the TC firm years split sample. The securitization variable is not significant for the Non-TC firm years split sample.

Consistent with our results using the Amtrecta variable, we find that the securitization variable is significantly positively related to market share for the TC firm years split sample, but there is no significant relation between securitization and market share for Non-TC firm years split sample. The relation between securitization and income growth also remains statistically insignificant for the overall sample and both split samples.

Overall, our results are robust to alternative specification of the securitization variable.

\section{CONCLUSION}

Prior research has documented a positive relation between the offering of trade credit and the generation of sales growth (Petersen and Rajan (1997)). While firms may wish to offer additional trade credit to boost sales, this strategy may not be viable for many firms who face liquidity constraints and cannot afford to delay the receipt of cash. Securitization can resolve this liquidity constraint by allowing firms to sell accounts receivable and receive cash payments.

We test whether securitization is associated with an increase in trade credit and find evidence of a positive relation in our full sample. However, subsample analysis shows that this positive relation occurs only for securitizing firms offering services or differentiated products (TC firms). For securitizing firms offering standardized goods (Non-TC firms), there is no relation between securitization and trade credit.

We also examine whether increases in securitization impact sales growth, market share and income growth. We find that the impact of securitization on sales growth and market share also depends on the nature of the good sold. Firms providing services or differentiated goods show a positive relation between securitization and sales or market share growth. In contrast, there is not a significant relation between securitization and sales or market share growth for firms producing standardized goods. This result is consistent with the finding of Giannetti et al (2011) that firms producing standardized goods rely less on the use of trade credit to generate sales.

We also examine whether securitization is associated with increased income growth. We show no significant relation between securitization and industry adjusted income growth. However, our measure of income growth is a short term measure. Firms may be willing to use securitization to provide funds to increase sales growth or market share even if short term income does not increase if they believe that the sales or market share gains will result in higher long term profits.

Our results contribute a previously unestablished link between trade credit and securitization and explain why firms offering services or differentiated goods may be more likely to use securitization facilities. 


\section{APPENDIX A}

\section{Accounting Treatment of Securitization}

In June 1996, the Financial Standards Accounting Board (FASB) issued statement No. 125. This statement was intended to address the accounting for transfers and servicing of financial assets. Under FASB Statement No. 125, the transfer of financial assets was accounted for as a sale (and thus removed from the firm's financial statement) if all of the following conditions were met:

1. The assets moved to the SPE are beyond the reach of the firm's creditors.

2. Either of the following:

- The SPE has the right to pledge or exchange the interest in the receivables

- The SPE is a qualifying special-purpose entity.

3. The company transferring the assets does not have control over the receivables transferred.

For securitizing firms, this meant that if they formed an SPE that was 'bankruptcy remote', then the first condition was met. If the SPE could be classified as a 'qualifying special-purpose entity' then the second condition was met. Finally, if there was no agreement for the parent company to repurchase the receivables from the SPE, then the third agreement was met. In these cases, the SPE could be excluded from the parent firm's balance sheet.

In 2000, FASB issued Statement No. 140. This statement was intended to adjust Statement No. 125. While the three requirements remained largely the same, there was an adjustment to what types of entities could be classified as 'qualifying special purpose entities'. The new requirement meant a third party (unrelated to the parent company), must hold $10 \%$ of the residual interest (an increase from the prior requirement of $3 \%$ ). Also, prior to this requirement, the parent company and its investment bank could be the only parties holding a share of the residual interest.

In 2003, FIN 46 was issued largely in response to recent events (Enron and Worldcom, etc). One of the large changes from FIN 46 was that instead of a percentage requirement for a third party residual interest, an SPE (termed 'Variable Interest Entity' or VIE in FIN 46) must now be consolidated if the transferring company bears the majority of the risk and also gets a majority of the rewards from the SPE.

Finally, the most recent changes occurred in 2009 with the issue of FASB statement No. 166, which eliminated the use of 'qualified special-purpose entities'. Additionally, Statement No. 166 clarifies that the accounting treatment of the assets rests upon the level of control the transferring firm maintains over the assets sold. In order to be considered a 'sale' and removed from the financial statement, the firm must transfer an entire financial asset or a group of entire financial assets and have no control of the entire transferred asset(s). In this case, the use of a qualifying special-purpose entity was no longer relevant to whether the SPE is consolidated with the firm's financial statement. Instead, the decision about consolidation is made based on whether the transfer of the financial assets counts as a 'true sale'. 


\section{APPENDIX B}

Example of Accounting Differences between Consolidated and Unconsolidated SPE's.

Dechow and Shakespeare (2009) provide an example of the accounting differences that take place when the SPE is not consolidated vs. consolidated. This example is provided verbatim below. The example begins by providing a sample firm's beginning balance sheet:

\begin{tabular}{lr}
\hline Opening Balance Sheet & \multicolumn{1}{c}{$\$$} \\
\hline Cash & 100 \\
Accounts Receivable & 0 \\
Inventory & 600 \\
Total Assets & $\underline{700}$ \\
Equity & 700 \\
Total Liability and Equity & 700 \\
\hline
\end{tabular}

The firm sells all inventory on credit for $\$ 1,000$ and securitizes the accounts receivable, receiving $\$ 900$ in cash from the SPE. The retained interest has a fair value of $\$ 110$.

Closing Balance Sheet

Collateralized Borrowing (Consolidated)

Cash

Accounts Receivable

Inventory

Total Assets

Liability

Equity

Total Liability and Equity
Closing Balance Sheet

$\$ \quad$ Gain on Sale (Unconsolidated)

Cash

1000

1000 Accounts Receivable

0 Inventory

Retained Interest

$\underline{2000}$ Total Assets

Liability

$\begin{array}{r}1110 \\ \hline \hline 0\end{array}$

1100 Equity

2000 Total Liability and Equity

\section{Income Statement}

Collateralized Borrowing (Consolidated)

Revenue

Cost of Goods Sold

Net Income

\begin{tabular}{rr} 
& \multicolumn{1}{c}{$\$$} \\
& 600
\end{tabular}

\section{Income Statement}

\begin{tabular}{lc} 
Gain on Sale (Unconsolidated) & $\$$ \\
\hline Revenue & 1000
\end{tabular}

Cost of Goods Sold

600

Gain on Sale

10

400

Net Income 


\section{APPENDIX C}

\section{VARIABLE DEFINITIONS}

The variables used throughout the article are as follows:

Trade Receivable is the sum of trade receivables plus the outstanding balance of trade receivables held at the SPE, divided by total assets plus the trade receivables held at the SPE

Days Receivables is measured as the ratio of trade receivables to daily sales. If a firm has an unconsolidated SPE, Trade Receivables is the sum of trade receivables plus the outstanding balance of trade receivables held at the SPE.

Financial Distress is an indicator variable equal to one if the firm is in financial distress according to the Asquith, Gertner and Scharfstein (1990) definition. This definition looks at the firm's coverage ratio (EBITDA/Interest Expense). If the coverage ratio is less than one in the current year and one year lagged, or if the coverage ratio for the current year is less than .8, then Financial Distress $=1$

Payables is accounts payables as a percentage of total assets.

Leverage is the book value of debt divided by total assets.

Sales Growth is the growth in firm sales from t- 1 to t.

Turnover is Inventory Turnover, computed as cost of goods sold divided by inventory.

Amtrecta is the total amount of money received by the firm from the sale of receivables to the SPE, as a percentage of total assets.

LnAssets is the natural log of total assets.

Market-to-Book is the ratio of the market value to book value of common equity, with book value of equity calculated as Total Assets - Total Liabilities - Preferred Stocks + Deferred Taxes + Convertible Debt

$R \& D$ is research and development expenses divided by total assets.

$P P E$ is gross property, plant and equipment divided by total assets.

LnAge is the natural log of firm age as measured by the first year of available Compustat data. LTDebt

Dummy is an indicator variable equal to 1 when the firm has a long-term debt rating, and

0 otherwise.

STDebtDummy is an indicator variable equal to 1 when the firm has a short-term debt rating and 0 otherwise.

$B B B$ is an indicator variable equal to 1 if the firm's long-term debt rating is equal to $\mathrm{BBB}+$, $\mathrm{BBB}$ or $\mathrm{BBB}-$

$B B$ is an indicator variable equal to 1 if the firm's long-term debt rating is equal to $\mathrm{BB}+, \mathrm{BB}$ or $\mathrm{BB}-$.

$B$ is an indicator variable equal to 1 if the firm's long-term debt rating is equal to B+, B or B-.

Below $B$ is an indicator variable equal to 1 if the firm's long-term debt rating is below B-.

Fin46 is an indicator variable equal to one for years following the adoption of FINA46 in 2003. Fin46 is an accounting standard that changed the accounting rules regarding the consolidation of securitization facilities.

AdjustedSalesGrowth $h_{t}$ is industry-adjusted firm sales growth from period $t-1$ to $t$, calculated as the one year change in industry-adjusted sales, where the industry adjustment is carried out by subtracting the Fama and French (1997) industry median from the firm's performance.

AdjustedIncomeGrowth is industry-adjusted firm income growth from period $t-1$ to $t$, calculated as the one year change in industry-adjusted income, with income measured as income before extraordinary items, and where the industry adjustment is carried out by subtracting the Fama and French (1997) industry median from the firm's performance.

Market Share Change is the change in firm market share from period $t-1$ to $t$. Firm market share is calculated by dividing the firm's sales by total sales for its 2-digit SIC code using Fama French (1997) industry classifications.

IndEarn/Assets $t_{t-1}$ is industry-adjusted earnings (EBITDA) as a percentage of assets, where the industry adjustment is carried out by subtracting the Fama and French (1997) industry median from the firm's performance. 
IndInvest/Assets ${ }_{t-1}$ is industry-adjusted investment as a percentage of assets, where the industry adjustment is carried out by subtracting the Fama and French (1997) industry median from the firm's performance.

IndAssetSales ${ }_{t-1}$ is industry-adjusted asset sales, where the industry adjustment is carried out by subtracting the Fama and French (1997) industry median from the firm's performance.

Receivables Decrease $_{t-1}$ is an indicator variable equal to one if the firm's decrease in trade receivables to assets is lower than the 10th percentile for the industry. 


\section{REFERENCES}

Asquith, P.; and R. Gertner. "Anatomy of Financial Distress: An Examination of Junk-Bond Issuers." Quarterly Journal of Economics, 109 (1994), 625-658.

Cuñat, V. "Trade Credit: Suppliers as Debt Collector and Insurance Providers." Review of Financial Studies, 20 (2007), 491-527.

Dass, N.; Kale, J.; and V. Nanda. "Trade Credit, Relationship-specific Investment and Product-market Power." Review of Finance, 19 (2015), 1867-1923.

Dechow, P.; Meyers, L.; and C. Shakespeeare. "Fair Value Accountings and Gains from Asset Securitizations: A Convenient Earnings Management Tool with Compensation Side-Benefits." Journal of Accounting and Economics, 49 (2009), 2-25.

Ferris, J.S. "A Transactions Theory of Trade Credit Use." Quarterly Journal of Economics, 96 (1981), 243-270.

Frank, M.Z.; and V.K. Goyal. "Capital Structure Decision: Which Factors Are Reliably Important?" Financial Management, 38 (2009), 1-37.

Giannetti, M.; Burkart, M.; and T. Ellingsen. "What You Sell is What You Lend? Explaining Trade Credit Contracts." Review of Financial Studies, 24 (2011), 1261-1298.

Hill, M.; Wayne Kelly G.; and B. Lockhart. "Shareholder Returns from Supplying Trade Credit." Financial Management, 41 (2012), 255-280.

Lee, Y.W.; and J.D. Stowe. "Product Risk, Asymmetric Information, and Trade Credit." Journal of Financial and Quantitative Analysis, 28 (1993), 285-300.

Lemmon, M.; Xiaolei Liu, L.; Qinghao Mao, M.; and G. Nini. "Securitization and Capital Structure in Non-financial Firms: An Empirical Investigation.” Journal of Finance, 9 (2014), 1787-1825.

Long, M.S.; Malitz, I.B.; and S.A. Ravid. "Trade Credit, Quality Guarantees, and Product Marketability." FM: The Journal of the Financial Management Association, 22 (1993), 117-127.

Longhofer, S.D.; and J. A. C. Santos. "The Paradox of Priority." Financial Management, 32 (2003), 69-81.

Meltzer, A. H. "Mercantile Credit, Monetary Policy, and Size of Firms." Review of Economics and Statistics, 42 (1960), 429-437.

Mian, S.; and C.W. Smith. "Accounts Receivable Management Policy: Theory and Evidence." Journal of Finance, 47 (1992), 169-2000.

Mills, L.; and K. J. Newberry. "Firms' Off-Balance Sheet and Hybrid Debt Financing: Evidence from Their Book-Tax Reporting Differences." Journal of Accounting Research, 43 (2005), 251-282.

Molina, C.; and L. Preve. "Trade Receivables Policy of Distressed Firms and Its Effect on the Costs of Financial Distress." Financial Management, 38 (2009), 663-686.

Nadiri, M. "The Determinants of Trade Credit in the U.S. Total Manufacturing Sector." Econometrica, 37 (1969), 408-423.

Petersen, M.; and R. Rajan. "Trade Credit Theories and Evidence." Review of Financial Studies, 10 (1997), 661-691.

Schwartz, R. "An Economic Model of Trade Credit." Journal of Financial and Quantitative Analysis, 9 (1974), 643-657.

Smith, J. "Trade Credit and Information Asymmetry." Journal of Finance, 4 (1987), 863-869.

Smith, J.K.; and C. Schnucker. "An Empirical Examination of Organizational Structure: The Economics of the Factoring Decision." Journal of Corporate Finance, 1 (1994), 119-138.

Summers, B.; and N. Wilson. "Trade Credit Management and the Decision to use Factoring: An Empirical Study.” Journal of Business Finance \& Accounting, 27 (2000), 37-68. 